\title{
PRODUCTION AND USE OF SECRETIONS PASSED BY MALES AT COPULATION IN PIERIS PROTODICE (LEPIDOPTERA, PIERIDAE)*
}

\author{
By Ronald L. Rutowski ${ }^{1}$ \\ Department of Zoology \\ Arizona State University \\ Tempe, AZ 85287
}

\begin{abstract}
INTRODUCTION
During copulation in many species of insects the male passes to the female sizeable quantities of accessory gland secretions with the sperm (Thornhill and Alcock, 1983). Recently it has been shown in the Lepidoptera that these secretions may represent a nutrient investment by the male that is used by the female in the production of eggs and in somatic maintenance (Boggs and Gilbert, 1979; Boggs, 1981; Boggs and Watt, 1981; Goss, 1977; Greenfield, 1982). Typically these secretions are contained within a spermatophore with the sperm or they may be passed as loose secretion. The perspective that these secretions may constitute a nutrient investment by males has some important implications for how male and female lepidopterans should behave (Marshall, 1982; Rutowski, 1982; see also, Gwynne, 1982).

In spite of recent interest in these secretions there are few studies of the patterns of their production and use within and between species of Lepidoptera (e.g., Boggs, 1981; Greenfield, 1982; Rutowski et al., 1983). This paper reports data on patterns of variation in the quantity of material passed to females during copulation by males of the checkered white butterfly (Pieris protodice Boisduval and LeConte) and the disappearance of these secretions from the female's reproductive tract. The secretions are received by the female in the bursa copulatrix which in this butterfly species is composed of two sacs, the corpus bursa and the appendix bursa. These are connected in series with the appendix bursa being furthest from the copulatory opening. During copulation the appendix bursa is filled with a whitish fluid and the corpus bursa is filled with
\end{abstract}

*Manuscript received by the editor March 5, 1984. 
a spermatophore that is formed within the bursa during copulation and contains sperm and secretions.

\section{Methods ANd Materials}

All observations were made at the Arizona State University Farm Laboratory from March to July in 1983. Here the butterflies use cultivated alfalfa as a nectar source and feral and cultivated crucifers as oviposition sites and larval foodplants. All hand-reared adults were grown from eggs collected in the laboratory or from young larvae collected in the field. In the laboratory larvae were reared either on broccoli (Brassica spp.) leaves or on cuttings of Sisymbrium irio L. in plastic shoe boxes under variable and uncontrolled conditions of light and humidity. The temperature in the laboratory was about $24^{\circ} \mathrm{C}$.

\section{Production of secretions during copulation}

To examine the patterns of production of secretions by males, virgin females were released next to free-flying males and permitted to copulate with them. If the copulation lasted $60 \mathrm{~min}$ or less, both members of the pair were freeze-killed after the pair separated. Longer copulations were thought to indicate dysfunction or recent mating by the male. Males in the mated pairs were assessed with respect to wing wear (age), forewing length, and body weight (to the nearest $0.1 \mathrm{mg}$ ) (for techniques, see Rutowski et al., 1983). Females were assessed with respect to forewing length and the volume and wet mass of material received from the male during copulation (for technique see Rutowski et al. 1983). In some cases males were weighed and measured without killing so that they could be held overnight (without food and water) and returned to the field the following day to observe their performance in second matings. Male precopulatory body mass was estimated by adding the mass of the secretions imparted to his postcopulatory mass.

To examine the rate of use of the material received during copulation virgin females were mated to free-flying males as above and then held in cylindrical screen cages $(9 \mathrm{~cm}$ diameter, $12 \mathrm{~cm}$ deep) in the laboratory under flourescent illumination. At various times after mating females were freeze killed and dissected to examine the material remaining in the bursa copulatrix. Sprigs of $S$. irio for oviposition and sugar water for food were available in these cages. 
All summary statistics are given as mean \pm standard deviation. The 0.05 level was used in all evaluations of statistical significance.

\section{RESULTS}

Production of secretions by males

Various aspects of the observed copulations and the individuals that participated in them are summarized in Table 1. Again, all these copulations were less than $60 \mathrm{~min}$ in duration. All males were in fresh or only slightly worn condition. Several significant positive correlations reflect concordance in the measuring techniques. Male forewing length was significantly positively correlated with the estimate of male precopulatory body mass (Fig. $1 \mathrm{~A} ; \mathrm{r}=0.71, \mathrm{n}=26$, $\mathrm{p}<10^{-5}$ ) and a similar relationship was found between the volume and the mass of male-imparted secretions (Fig. $1 \mathrm{~B} ; \mathrm{r}=0.879, \mathrm{n}=28$, $\mathrm{p}<10^{-9}$ ).

Qualitative microscopic observations were made on squash mounts of material removed from the spermatophore and the appendix bursa found in 3 females. These observations suggest that the sperm packet is (1) discrete from the non-sperm matieral, (2) last to be deposited in the bursa copulatrix (closest to the bursal entrance), and (3) typically consititues $10 \%$ or less of the volume of material passed by the male.

On average males passed almost $8 \%$ of their precopulatory body mass at copulation. However, the quantity of material passed measured by volume or mass was not significantly correlated with either male forewing length (vs. volume: $r=-0.054, n=28, p=0.39$; vs. mass: $r=-0.108, n=28, p=0.29$ ) or male precopulatory body mass (vs. volume: $r=-0.095, n=26, p=0.32$; vs. mass: $r=0.0066$, $n=26, p=0.48)$. The percent of male precopulatory body mass passed at copulation was significantly negatively correlated with both measures of male size (Fig. 2; forewing length: $r=-0.625$, $\mathrm{n}=26, \mathrm{p}=0.0003$; precopulatory body mass: $\mathrm{r}=-0.654, \mathrm{n}=26, \mathrm{p}=$ 0.0001 ). These results suggest that all males regardless of size pass a typical amount of material. Small males must then obviously pass a larger proportion of their body mass to achieve this typical quantity.

Copulation duration was not significantly correlated with the volume of material passed $(r=-0.243, n=26, p=0.115)$ but was significantly negatively correlated with the mass of secretions passed by males (Fig. $3 ; \mathrm{r}=-0.34, \mathrm{n}=26, \mathrm{p}=0.045$ ). There may be a 
Table 1. Summary of 28 copulations that lasted $60 \mathrm{~min}$ or less.

\begin{tabular}{lcccc} 
Variable (units) & Mean & $\begin{array}{c}\text { Standard } \\
\text { deviation }\end{array}$ & $\begin{array}{c}\text { Sample } \\
\text { size }\end{array}$ & Range \\
\hline $\begin{array}{l}\text { Male forewing length (mm) } \\
\begin{array}{l}\text { Estimate of male precopulatory } \\
\quad \text { body mass (mg) }\end{array}\end{array}$ & 23.9 & 1.1 & 28 & $21-26$ \\
$\begin{array}{l}\text { Female forewing length (mm) } \\
\quad \begin{array}{l}\text { Copulation dura- } \\
\quad \text { tion (min) }\end{array}\end{array}$ & 52.9 & 10.9 & 26 & $29.1-70$ \\
$\quad$ & 31.7 & 9.23 & 26 & $22-60$ \\
$\quad \begin{array}{l}\text { Volume of male-imparted } \\
\quad \text { secretions }(\mu)\end{array}$ & 3.44 & 1.08 & 28 & $1.36-5.46$ \\
$\quad \begin{array}{l}\text { Mass of male-imparted } \\
\quad \text { secretions (mg) }\end{array}$ & 3.89 & 1.15 & 28 & $1.78-5.9$ \\
$\quad$ of male body mass passed & 7.88 & 2.59 & 26 & $2.7-12.7$ \\
\hline
\end{tabular}

tendency in copulations lasting an hour or less for females to receive smaller quantities of material than in long copulations.

Female forewing length was not significantly correlated with male forewing length $(r=-0.0404, n=28, p=0.42)$ which suggests size assortative mating does not occur in this species. Female forewing length was not significantly correlated with the volume of secretions received $(r=-0.25, n=28, p=0.10)$ or the mass of secretions received $(r=0.228, n=26, p=0.122)$. Female size apparently does not influence the quantity of material passed.

Ten males were mated and then successfully remated 24 hours later. Table 2 summarizes a comparison of first and second matings by these males. Statistical comparisons reveal that significantly less material was passed in the second matings $(\mathrm{t}=4.32,9 \mathrm{df}, \mathrm{p}<0.002)$ and males passed a significantly smaller proportion of their body mass $(\mathrm{t}=3.3,9 \mathrm{df}, \mathrm{p}<0.01)$. Although not all copulation durations were precisely measured, those that were displayed no difference between the durations of first and second matings separated by 24 hrs $(\mathrm{t}=0.107,15 \mathrm{df}, \mathrm{p}=0.46)$.

Rate of use of male secretions by female

Fig. 4 shows the mass of material remaining in the females's reproductive tract at various times after mating. During the first day or two after copulation little material has left the bursa copulatrix but then the decline is rapid until day 5 at which point it seems to level off. The correlation between days since copulation and material left in the bursa copulatrix was negative and highly significant $\left(\mathrm{r}=-0.751, \mathrm{n}=46, \mathrm{p}<10^{-8}\right)$. 


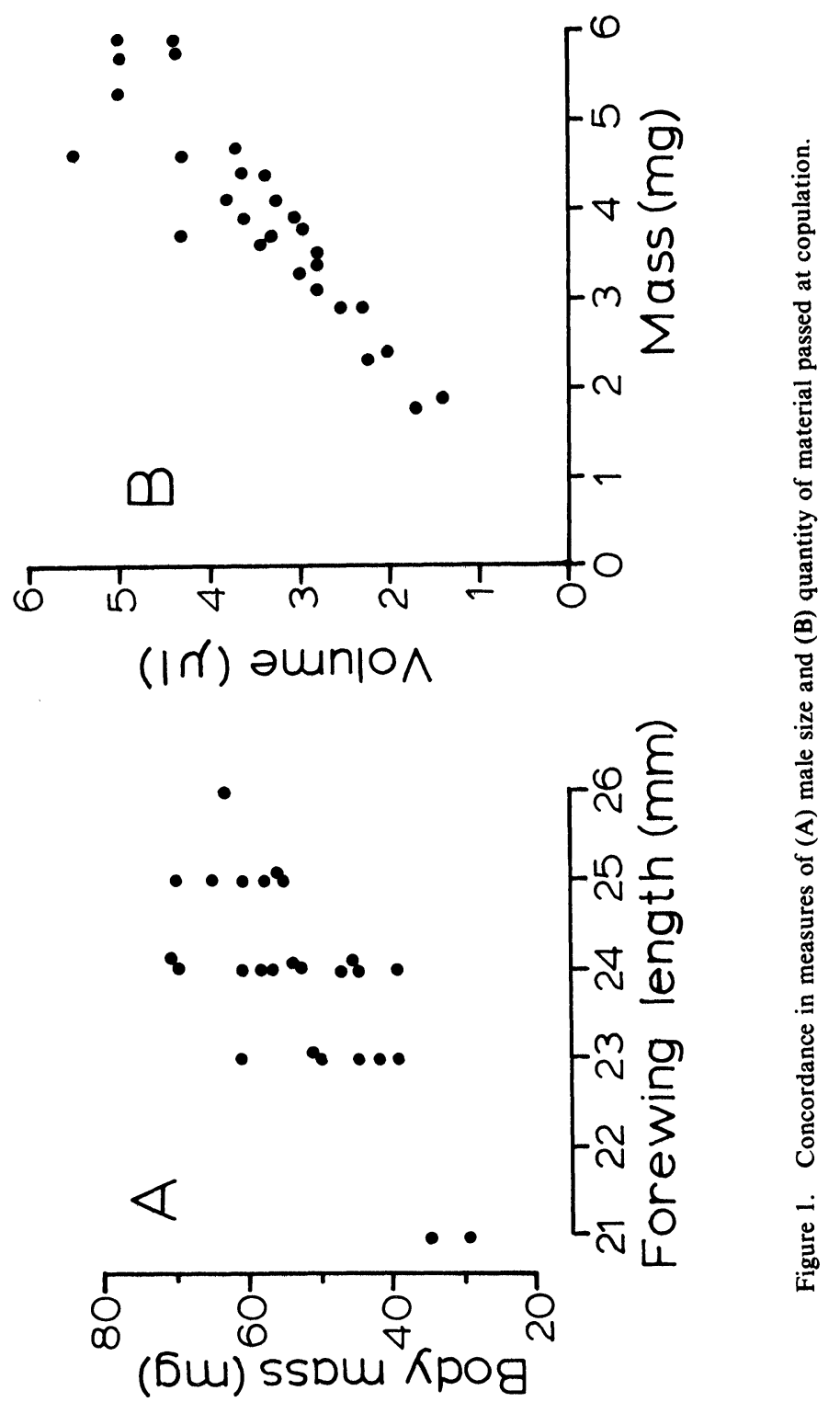




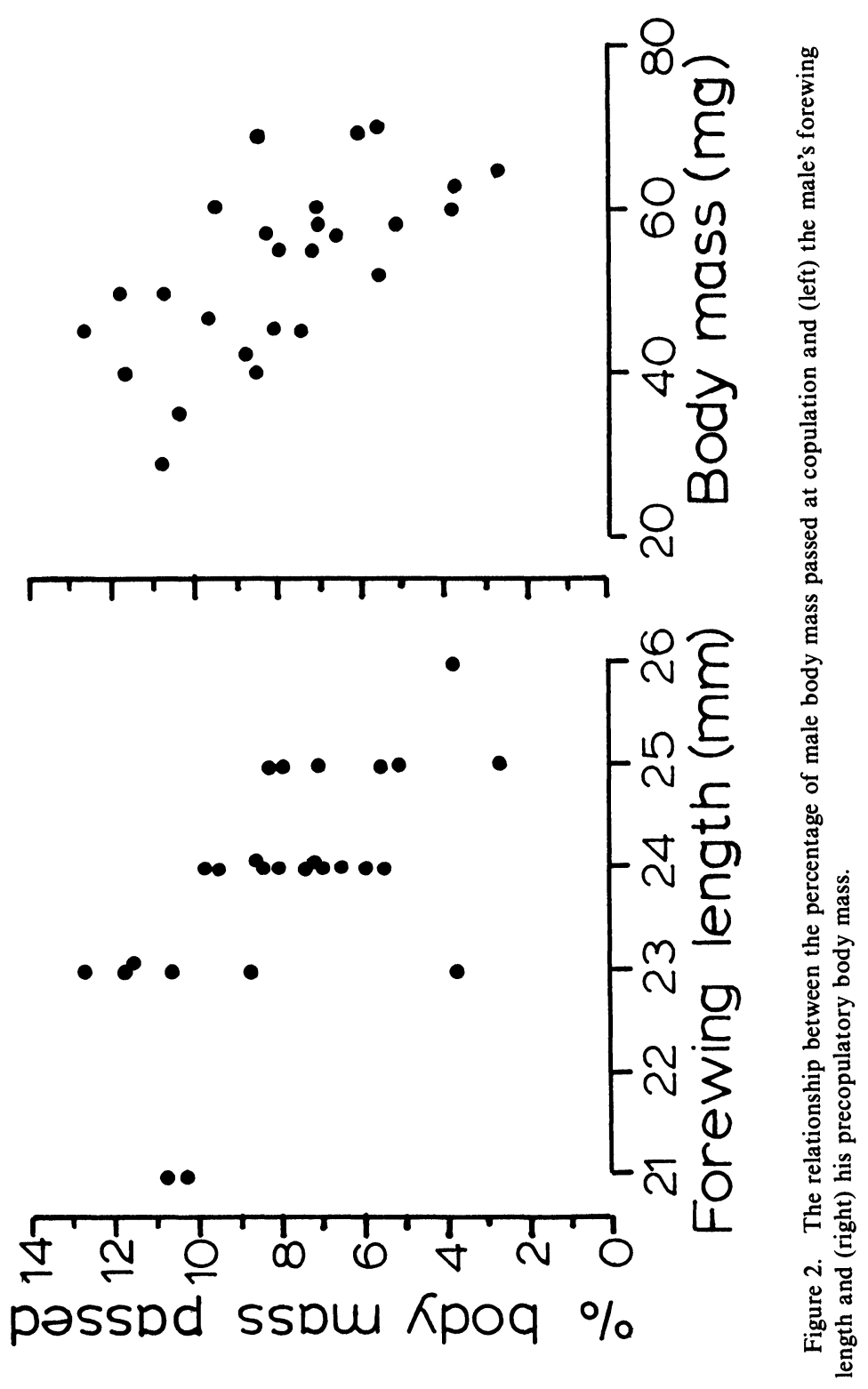


The conditions under which these females were kept in the laboratory were admittedly highly artificial and restricted the females's movements. As a result oviposition behavior was erratic but several major trends were apparent. No female oviposited before day two after copulation. Hence, depletion of the secretions begins at the same time as the production of eggs. The maximum number of eggs produced by any female was 114 . The number of eggs produced was not significantly positively correlated with the number of days since copulation $(r=0.306, n=25, p=0.07)$. No female laid infertile eggs regardless of time since mating and number of eggs laid.

\section{Observations on field-caught females}

Seventy-three females were collected in the field during this study for examination of the contents of their reproductive tracts. Of these only one was a virgin, 56 carried one spermatophore, and 15 carried two spermatophores meaning they had mated twice. The likelihood of a female mating twice increased with age as indicated by wing wear. Of 30 fresh females $10 \%$ were twice mated while of 41 females that showed noticeable wing wear $29 \%$ were twice mated $\chi^{2}=3.86,2$ df, $\mathrm{p}<0.05$ ). In 9 of the twice mated females it was evident that the female only remated when the spermatophore from the first mating was in a greatly depleted state. In these females, the spermatophore furthest from the entrace to the bursa copulatrix was collapsed and clear in color while the other had its neck or collum extending into the ductus bursa and was full, white, and round.

\section{Discussion}

\section{Production of secretions by males}

Males of $P$. protodice pass on average 7-8\% of their body mass at a single copulation. This figure is in the range of values observed in a variety of butterflies by Rutowski et al. (1983). Moreover, the courtship behavior of Pieris protodice follows the basic pattern observed in other butterflies: the male approaches the female, the female alights, the male buffets the female briefly with his wings, the male alights and couples with the female (Rutowski, 1979a). These data support the hypothesis of Rutowski et al. (1983) that a lack of interspecific diversity in the overall complexity of butterfly courtship behavior is paralleled by a lack of variation between species in the proportion of male body mass passed at copulation. 


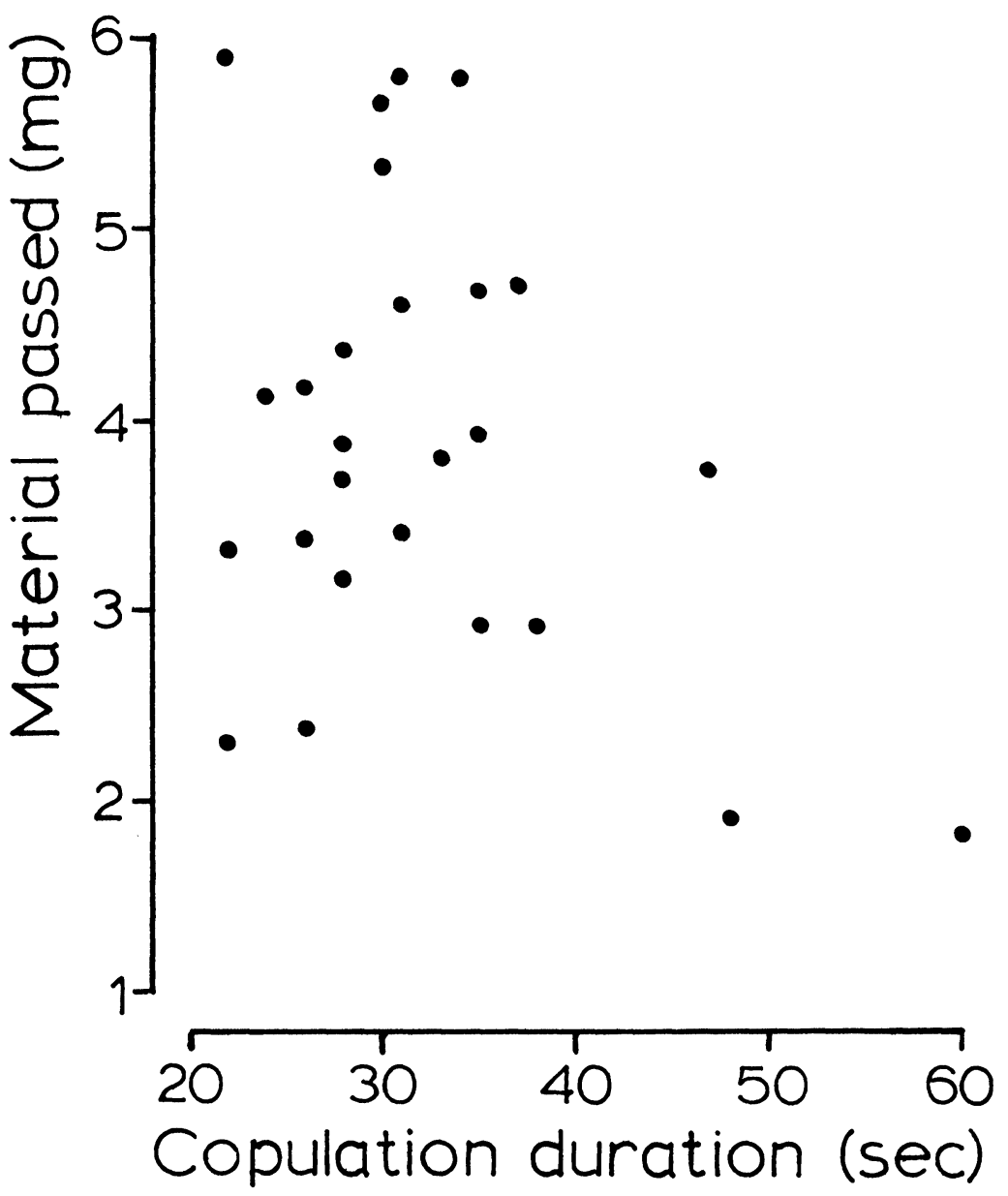

Figure 3. The relationship between the mass of material passed by a male at copulation and the duration of copulation.

The quantity of material passed by a male was not related to his size, contrary to observations made by Boggs (1981) on a heliconiine butterfly, Greenfield (1982) on a pyralid moth, and Gwynne (1982) on a katydid. However, males, independent of size, produce a typical quantity of material during a copulation and the proportion of a male's body mass passed varies inversely with male size. Because of the critical role inflation of the bursa copulatrix plays in 
Table 2. A comparison of the performance of males in matings separated by 24 hours. See text for details.

\begin{tabular}{|c|c|c|c|c|c|c|}
\hline \multirow[b]{2}{*}{ Parameter (units) } & \multicolumn{3}{|c|}{ First copulation } & \multicolumn{3}{|c|}{ Second copulation } \\
\hline & $\mathrm{X} \pm \mathrm{SD}$ & $\mathbf{N}$ & Range & $\mathrm{X} \pm \mathrm{SD}$ & $\mathbf{N}$ & Range \\
\hline $\begin{array}{l}\text { Copulation dura- } \\
\text { tion }(\mathrm{min})\end{array}$ & $33.2 \pm 11.8$ & 10 & $22-60$ & $32.6 \pm 10.8$ & 7 & $23-54$ \\
\hline $\begin{array}{l}\text { Mass of material } \\
\text { passed (mg) } \\
\% \text { of male body }\end{array}$ & $4.47 \pm 1.44$ & 10 & $1.78-5.9$ & $2.37 \pm 0.504$ & 12 & $1.45-3.12$ \\
\hline $\begin{array}{l}\text { mass passed } \\
\text { Volume of ma- } \\
\text { terial corpus }\end{array}$ & $8.8 \pm 1.95$ & 10 & $2.75-12.7$ & $5.88 \pm 0.898$ & 10 & $4.7-6.95$ \\
\hline $\begin{array}{l}\text { bursa } \\
(\mu)\end{array}$ & $3.63 \pm 0.997$ & 10 & $1.56-4.6$ & $1.85 \pm 0.411$ & 12 & $1.18-2.52$ \\
\hline
\end{tabular}

stimulating female refractoriness to courtship immediately after mating (Sugawara 1979) selection must favor males that produce a quantity of material that will cause most females to be unreceptive after mating. Sperm precedence has been shown in another pierid (Boggs and Watt, 1981) so stimulating female refractoriness will help protect a male's investment from exploitation by other males.

The lack of a relationship between male size and the absolute quantity of material a male is likely to pass may help understand the observation that very few unsuccessful courtships were observed during this study or in another (Rutowski, 1979a) that were lengthy and thereby suggested termination by the female. This is in contrast to recent observations on Colias eurytheme Boisduval in which almost half of all observed unsuccessful courtships were apparently female-terminated (Rutowski, unpublished data). In P. protodice choice by females on the basis of size among males may not yield significant material benefits. In a pyralid moth (Plodia interpunctella), Greenfield (1982) found that male size was proportional to mating success and that large males passed larger quantities of material. However, female egg output was not related to the size of her mate.

In a previous study of $P$. protodice, males in copulations separated by an average of only $10 \mathrm{~min}$ produced one quarter of the material in the second copulation that they produced in the first (Rutowski, 1979b). In that study the quantity of material passed was assessed only by estimating the volume of secretions passed into the spermatophore. Similar assessments are given in this study for first 


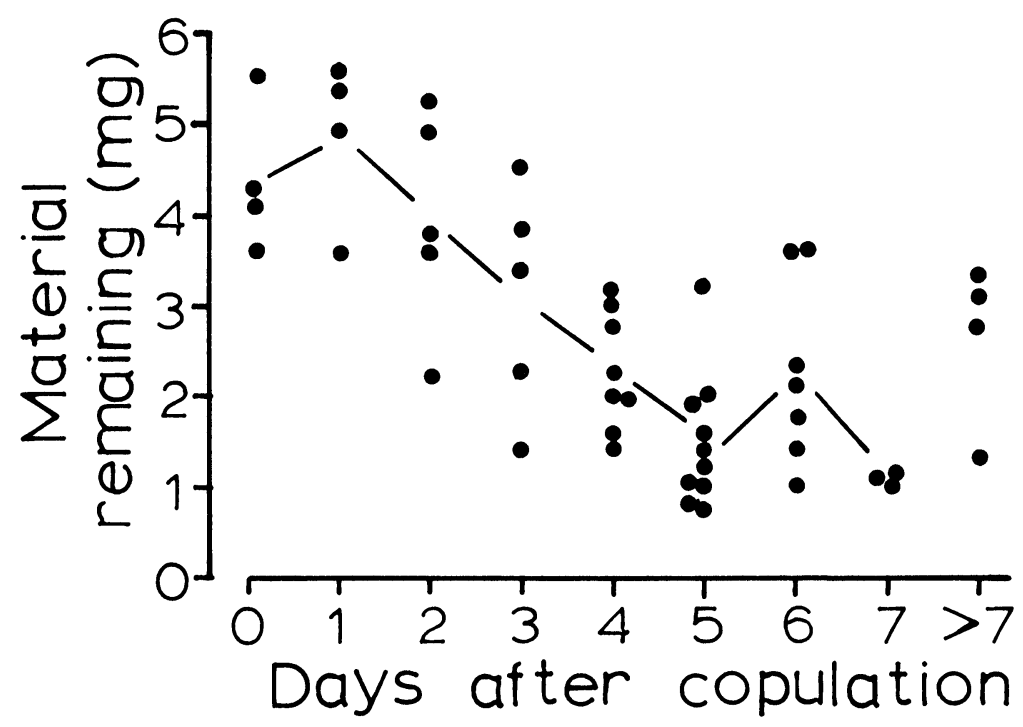

Figure 4. The quantity of material remaining in the female's bursa copulatrix as a function of the time since copulation. Line shows change in mean values for days 0 through 7 .

and second matings separated by $24 \mathrm{hrs}$ (Table 2). Several comparisons are valuable here. First, there was no significant difference between the amount of material passed in first copulations in 1979 and $1983(\mathrm{t}=0.614,26 \mathrm{df}, 0=0.27)$. In addition, males passed significantly more material $24 \mathrm{hrs}$ after the first mating than they did $10 \mathrm{~min}$ after the first mating $(\mathrm{t}=2.95,17 \mathrm{df}, \mathrm{p}=0.004)$. These comparisons point out the consistency in the observations between the two years and more importantly that while copulation durations indicate that males have substantially recovered in $24 \mathrm{hr}$ their supply is still somewhat depleted. However, this depletion may be a result of housing males between matings without food and water. In fact most of these males flew immediately to nectar sources upon release in the field. There is much to be learned about the performance of males in third matings and their performance in second matings when they have access to nectar.

Use of secretions by females

The rate at which females deplete the secretions they have received from males is greatest between the second and fifth days 
after mating. This suggests that a female's supply of secretions but not sperm is effectively depleted beginning at about six days after mating. Suzuki (1979) examined the phenomenon of multiple mating in Pieris rapae L., a close relative of $P$. protodice, and found that most females mate for the second time about 6 to 8 days after being released as a virgin in the field. These data support Suzuki's hypothesis that Pieris females may multiply mate to gain nutrients in that they appear to be doing so at a time when their supply of secretions from previous matings is largely depleted. This hypothesis is also confirmed by the data from the dissections of fieldcollected females in which at least one of the spermatophores carried by twice-mated females was often small and greatly depleted.

\section{SUMMARY}

This study examines the production and use of secretions passed by a male during copulation to a female in the checkered white butterfly (Pieris protodice). Males pass about 7 to 8 percent of their body weight at copulation in the form of secretions deposited in the female's reproductive tract. No correlation between the quantity of material passed and male size was found. However, it was found that the proportion of male body mass passed was inversely correlated with body mass suggesting that all males, regardless of size pass a typical quantity of material. A mating depletes the material a male has for subsequent mating but only temporarily. Males were found to have mostly recovered their potency in $24 \mathrm{hrs}$, even without food or water between matings.

Females have mostly depleted the material received from males in about 5 to 7 days. In the field females carrying multiple spermatophores always had one that was greatly depleted indicating that they remate only when material from a previous mating was depleted. The results are compared to information on the use and production of male-imparted secretions and mating behavior in other butterflies.

\section{ACKNOWLEDGEMENTS}

I thank John Schaefer and Scott Snead for their assistance in the field and laboratory. Financial support was provided by National Science Foundation Grants BNS 80-14120 and BNS 83-00317. 


\section{REFERENCES}

BogGs, C. L.

1981. Selection pressures affecting male nutrient investment at mating in heliconiine butterflies. Evolution 35: 931-940.

Boggs, C. L. AND L. E. Gilbert.

1979. Male contribution to egg production in butterflies: evidence for transfer of nutrients at mating. Science 206: 83-84.

Boggs, C. L. AND W. B. Watt.

1981. Population structure of pierid butterflies. IV. Genetic and physiological investment in offspring by male Colias. Oecologia 50: 320-324.

Goss, G.

1977. The interaction between moths and pyrrolizidine alkaloid-containing plants including nutrient transfer via the spermatophore in Lymire edwardsii (Ctenuchidae). Ph.D. Thesis, University of Miami.

GWYNNE, D. T.

1982a. Male nutritional investment and the evolution of sexual differences in Tettigoniidae and other Orthoptera. Pages 337-366 in D. T. Gwynne and G. K. Morris, ed., Orthopteran Mating Systems: Sexual Competition in a Diverse Group of Insects. Westview Press, Boulder.

1982b. Mate selection by female katydids (Orthoptera: Tettigoniidae, Conocephalus nigropleurum). Anim. Behav. 30: 734-738.

GREeNFIELD, M. D.

1982. The question of paternal investment in Lepidoptera: male-contributed proteins in Plodia interpunctella. Int. J. Invert. Reprod. 5: 323-330.

Marshall, L. D.

1982. Male nutrient investment in the Lepidoptera: what should males invest? Amer. Nat. 120: 273-279.

Rutowski, R. L.

1979a. Courtship behavior of the checkered white, Pieris protodice (Pieridae). J. Lep. Soc. 33: 42-49.

1979b. The butterfly as an honest salesman. Anim. Behav. 27: 1269-1270.

1982. Mate choice and lepidopteran mating behavior. Florida Ent. 65: 72-82.

Rutowski, R. L., M. Newton and J. Schaefer.

1983. Interspecific variation in the size of the nutrient investment made by male butterflies during copulation. Evolution 37: 708-713.

Sugawara, T.

1979. Stretch reception in the bursa copulatrix of the butterfly, Pieris rapae crucivora, and its role in behaviour. J. Comp. Physiol. 130: 191-199.

Suzuki, Y.

1978. Adult longevity and reproductive potential of the small cabbage white, Pieris rapae crucivora Boisduval (Lepidoptera: Pieridae). Appl. Ent. Zool. 13: 312-313.

Thornhill, R. AND J. Alcock.

1983. The Evolution of Insect Mating Systems. Harvard University Press, Cambridge. 

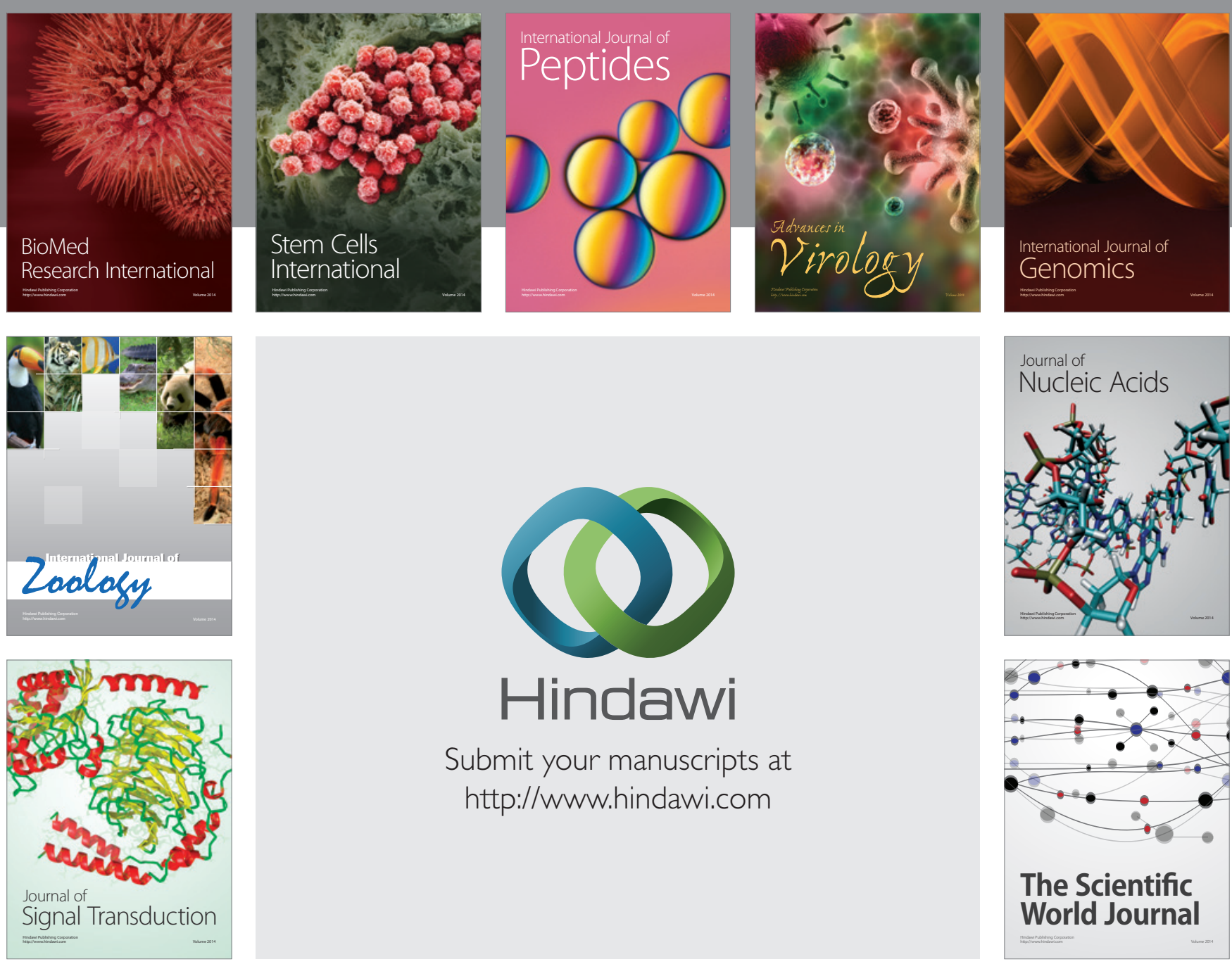

Submit your manuscripts at

http://www.hindawi.com
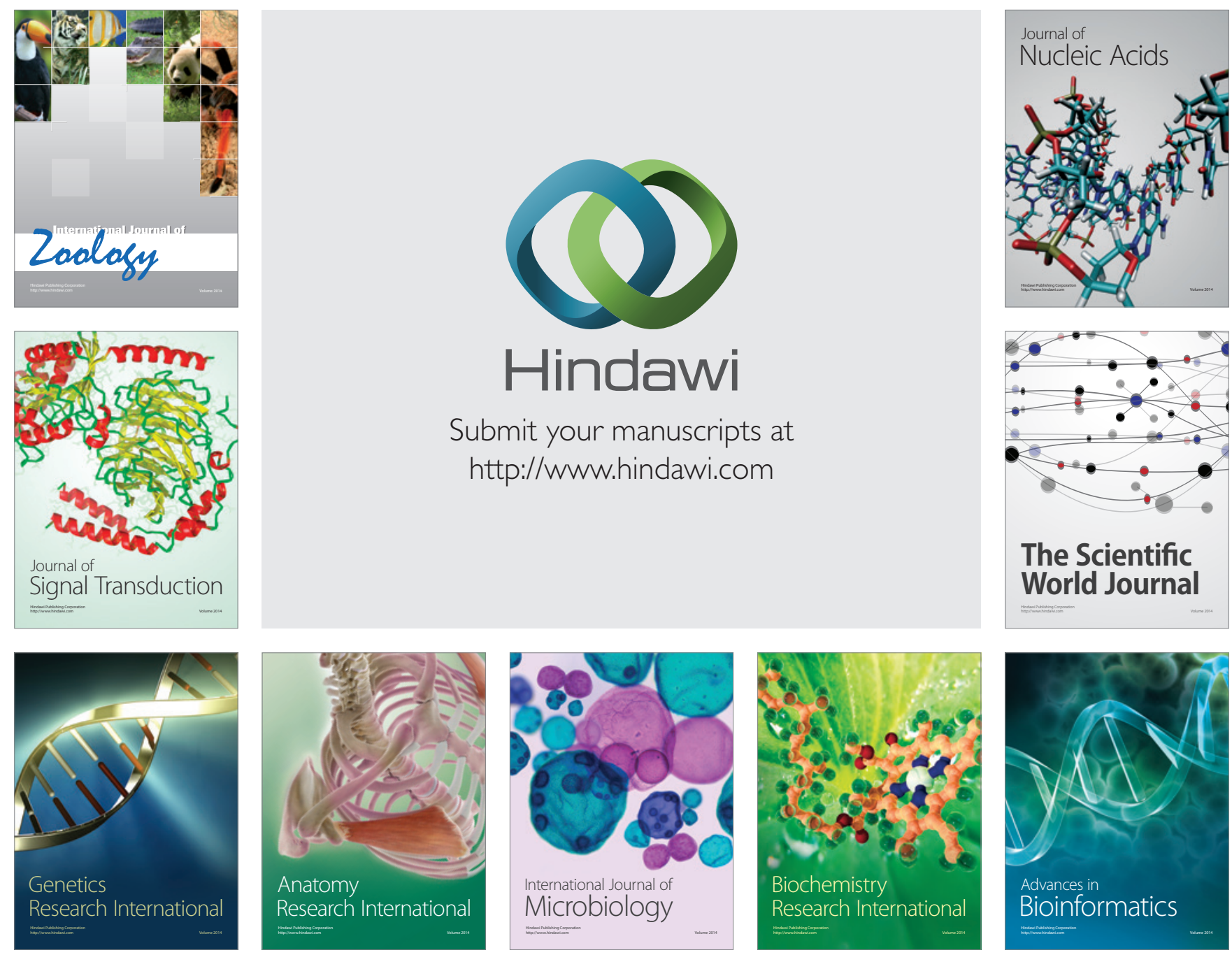

The Scientific World Journal
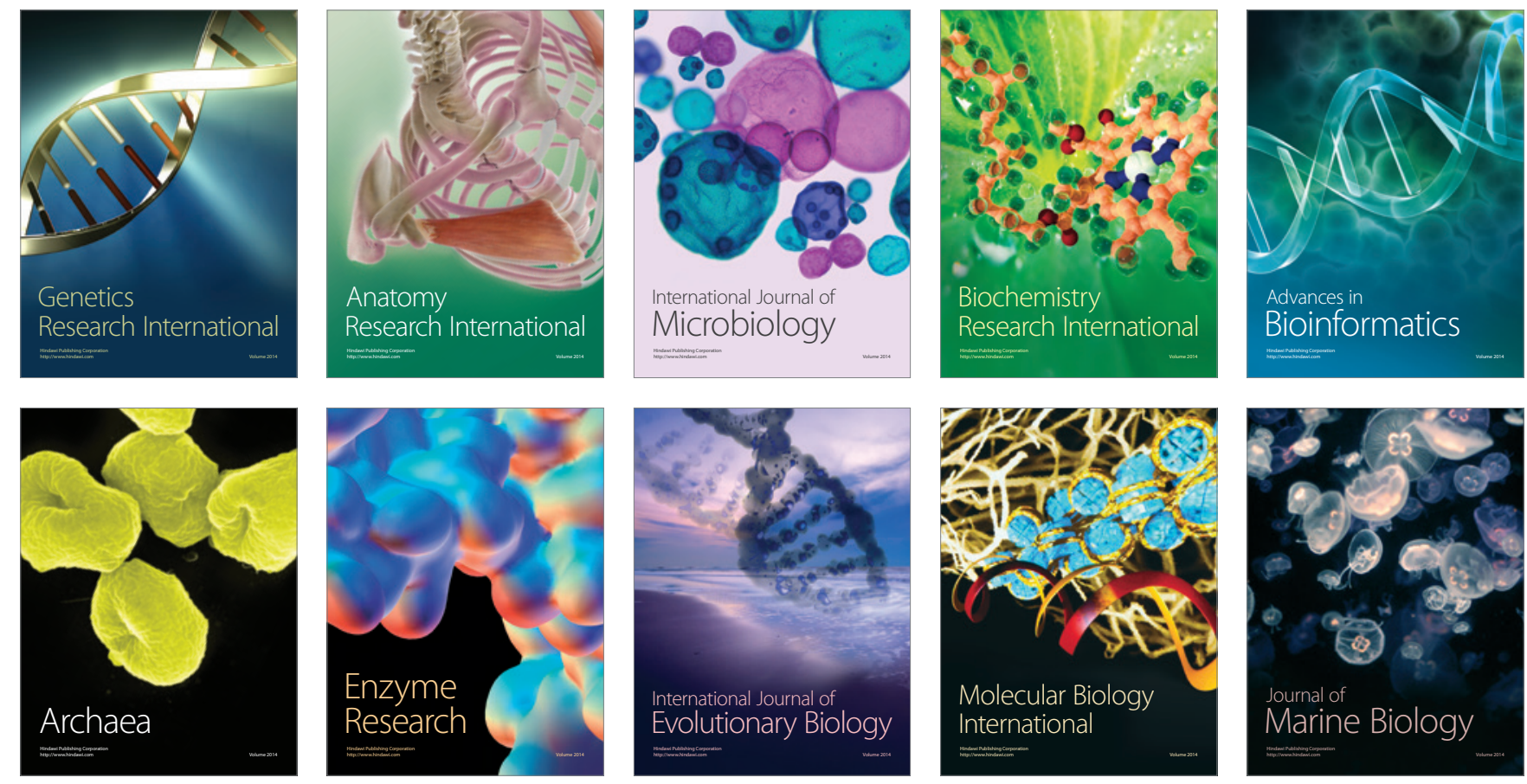